\title{
El adversario interior
}

\author{
DIEGO SÁNCHEZ MECA
}

\section{El MiLitANTE WAGNERIANO}

Se dice de El nacimiento de la tragedia que es un libro escrito para gloria y enaltecimiento de la música. Los dioses Dioniso y Apolo determinan, según el joven Nietzsche, el surgimiento de la tragedia ática antigua de la que pretende ser heredero, varios siglos después, el drama musical wagneriano. Tal vez sea en relación a este aspecto como mejor se muestre el carácter de campo de batalla que tiene este libro de juventud, en el que el propio Nietzsche se nos muestra en lucha consigo mismo, debatiéndose con contradicciones de las que sólo más adelante, con tiempo y esfuerzo, logra en parte liberarse. Schopenhauer y Wagner, bajo cuyo influjo se elaboran y se encadenan las tesis iniciales del pensamiento nietzscheano, se insinúan aquí ya, fuera de Nietzsche mismo, como el reflejo de su propio trasfondo nihilista, romántico y cristiano del que quiere desprenderse. La batalla se desarrolla, en definitiva, para destruir y deshacer, desde su inicial formulación misma, la primera condición de posibilidad del pensamiento nietzscheano: la expresión de las intuiciones de lo dionisíaco y lo trágico mediante fórmulas schopenhauerianas y wagnerianas ${ }^{1}$. De modo

1 Cf. F. Nietzsche, «Ensayo de autocrítica», en El nacimiento de la tragedia, tr. A. Sánchez Pascual, Madrid, Alianza, 1978, p. 29 (en adelante NT). 
que uno de los principales problemas que encierra El nacimiento de la tragedia (y los escritos de juventud en su conjunto) es el del antagonismo, el de la tensa y ambigua relación entre Nietzsche y Wagner cada vez más amenazada por la percepción, confusa al principio, que Nietzsche va teniendo de los motivos por los que la obra y el pensamiento estético de su admirado maestro terminarán por resultarle un camino imposible e intransitable.

Sustancialmente, la Stimmung de la obra tanto de Schopenhauer como de Wagner es llamar a una especie de 'vuelta a la naturaleza' en el espíritu de la mentalidad romántica del XIX, que responde a ciertas necesidades y problemas de la época. Esta vuelta a la naturaleza se plantea como un modo de lucha contra lo inauténtico, contra la mentira y las máscaras de la cultura, o sea, contra sus convenciones y su moral. Schopenhauer combate en este frente magnificando la voluntad y devaluando el mundo de la representación, que queda subordinado a las fuerzas inconscientes y prelógicas del querer vivir, mientras Wagner, por su parte, ennoblece las pasiones como fuente de toda grandeza y de toda verdadera sabiduría ${ }^{2}$. El joven Nietzsche se encuentra convencido y como aprisionado en este modo de pensar hasta el punto de militar como miembro activo en las filas del partido wagneriano. Cuando unos años más adelante — a la altura de 1878 - tras la ruptura con Wagner, eche la vista atrás, verá en este querer volver a la naturaleza sólo «impulsos a huir de la razón y del mundo» 3 , «la cultura como máscara y la riqueza como consecuencia de una incultura real, de una grosería interior y de una sensualidad repugnante» ${ }^{4}$. Esboza entonces un esquema de explicación a modo de balance de su trayectoria hasta ese momento (1878) donde lo que le importa resaltar es, más que cualquier otra cosa, su actitud y su posición teóricas ahora, en el momento de llevar a cabo este juicio. Dice el importante fragmento que contiene este balance: «Comprensión del peligro de la cultura... Debilitamiento del concepto de cultura: el nacionalismo, los filisteos de la cultura, la enfermedad histórica. ¿Qué apoyo encontrar frente a la epidemia?: 1) La metafísica de Schopenhauer (por encima de la histo-

2 F. Nietzsche, Nachgelassene Fragmente (en adelante NF), Kritische Studienausgabe (en adelante KSA), ed. G. Colli y M. Montinari, Berlin, Gruyter 1980. Aquí NF 1878, 30[134], en KSA 8.

NF 1878, 30[148].

4 NF 1878, 30[162]. 
ria, pensador heroico, posición casi religiosa); 2) El arte de Wagner... Pero entonces surgen nuevos peligros: lo metafísico incita al desprecio de lo efectivamente real y, en tal sentido, es hostil a la cultura y más peligroso todavía; y entre los wagnerianos predomina el egoísmo y la simbolización. Me alejé del arte, de la poesía (aprendí a entender mal la Antigüedad) y de la naturaleza... Significado de Bayreuth para mí: huida, jarro de agua fría; el arte, la naturaleza y la dulzura regresan»'5.

He aquí, muy someramente indicados, los trazos del itinerario recorrido por el joven Nietzsche hasta su distanciamiento de Wagner. Que también él luchaba contra la cultura de su época (vista como 'peligro') con las armas que le ofrecen Schopenhauer y Wagner, lo testimonian, no sólo El nacimiento de la tragedia, sino también sus Consideraciones intempestivas: la primera va dirigida contra filisteos de la cultura como David Strauss; la segunda trata de salir al paso de la 'enfermedad histórica'; y en la tercera y cuarta, dedicadas respectivamente a Schopenhauer y Wagner, Nietzsche desarrolla una crítica de la cultura desde la metafísica y la nueva música. Ahora, pasados ya algunos años, se da cuenta de los 'peligros' que estas posiciones entrañaban. Le preocupa lo que de rechazo de la cultura, sin más, suponía aquella lucha contra la mentira desde la que se promovía una 'vuelta a la naturaleza'. Especialmente claro ve ahora el antagonismo entre aquel impulso romántico regresivo y el espíritu de la Ilustración, que apuesta por la razón, el conocimiento y otra clase de crítica: «Nuestra más reciente música alemana... surge de una cultura que adolece de rápida decadencia. Su suelo es ese período de reacción y restauración en el que tanto un cierto catolicismo del sentimiento como el gusto por toda la esencia y la protoesencia autóctono-nacional florecieron y difundieron por Europa una fragancia mixta, orientaciones ambas del sentir que, tomadas en su máxima intensidad y llevadas a sus límites más extremos, acabaron por resonar en el arte wagneriano. La apropiación por parte de Wagner de antiguas sagas indígenas, el ennoblecedor manejo al que a su antojo sometió a los bien extraños dioses y héroes de éstas (los cuales son fieras soberanas con veleidades de melancolía, magnanimidad y tedio vital), la reanimación de estas figuras, a las que agregó la sed cristiano-medieval de sensualidad y desensualización extáticas, todo este forcejeo wagneriano 
respecto a asuntos, almas, figuras y palabras expresa el espíritu de su música..., que encabeza la última guerra y reacción contra el espíritu de la Ilustración que desde el siglo pasado soplaba en éste» 6 .

También ve ahora con claridad su malentendido respecto a la Antigüedad. Fue un completo error asimilar el espíritu de la tragedia griega a la música de Wagner. No hay modo de reducir aquí el contraste. Pues lo que caracteriza en su conjunto a la cultura de los griegos es la búsqueda de la mesura mediante el dominio de la voluntad, y lo que anima al arte de Wagner es un deseo de liberación como desencadenamiento y descontrol de la voluntad: «Los artistas griegos aplicaban su fuerza al refrenamiento, mientras los artistas de ahora lo hacen al desenfreno. ¡Qué contraste! Dominio de la voluntad frente a desenfreno» 7 . La fuerza de los griegos estaba en saber vencer y sublimar los instintos 8 , mientras que el arte de Wagner — presidido por una intención tiránica - no es capaz de producir más que un efecto narcótico y estupefaciente9. La ruptura con Wagner le permite a Nietzsche salir de estos errores y alcanzar una visión distinta y original del arte y de la Antigüedad: «De esto me fui dando cuenta afligido, y no pocas veces incluso con súbito espanto. Pero finalmente sentí que, tomando partido contra mí y mis preferencias, sentía el aliento y el consuelo de la verdad, con lo que me sobrevino una dicha mucho mayor que aquella a la que entonces volvía voluntariamente la espalda» ${ }^{10}$. Su intención ahora es, por así decirlo, tratar de hacer que Schopenhauer y Wagner «tomen partido contra ellos mismos» ${ }^{11}, y$

6 F. Nietzsche, Opiniones y sentencias varias, § 171, en Humano, demasiado humano, ed. A. Brotons, Madrid, Akal, 1996, vol. II, p. 58; «Schopenhauer y Wagner de acuerdo con su época: no más mentira ni convención, no más costumbre ni eticidad. Monstruosa confesión de que se trata del más salvaje egoísmo. Sinceridad, o sea, ebriedad en vez de moderación» NF 1878, 30[155].

7 NF 1878, 30[151].

8 Véase mi «Estudio preliminar» a F. Nietzsche, El culto griego a los dioses, Madrid, Alderabán, 1999.

9 Cf. Opiniones y sentencias varias, $\$ \S 144$ y 250; «Los efectos de la retórica wagneriana son tan brutales que después nuestro entendimiento ejerce la venganza: sucede como con el prestigiditador. Se critica más severamente los medios con que Wagner obtiene su efecto. Nos fastidia que Wagner no haya encontrado medios más refinados para atraernos» NF 1878, $30[183]$.

10 NF 1878, 30[190].

11 NF 1878, 30[85]. 
retractarse él mismo de su juvenil «estética peligrosa, cuyo esfuerzo se dirigía a hacer milagros de todos los fenómenos estéticos» ${ }^{12}$.

\section{LOS PELIGROS DE UNA ESTÉTICA DE JUVENTUD}

Pero, ¿qué aspectos de esta estética de juventud, de la que Nietzsche parece querer desdecirse a la altura de 1878, constituyen los 'peligros' que ahora trata de neutralizar? Obviamente los que condicionan, sobre todo, su comprensión de lo dionisíaco desde los parámetros schopenhaueriano-wagnerianos. El Nacimiento de la tragedia desarrolla una contraposición entre un arte apolíneo y un arte dionisíaco enmarcada, por un lado, en la metafísica schopenhaueriana de la voluntad como ser verdadero (das Wabrbaft-Seiende) del que surge el mundo de los fenómenos como mundo aparente, y orientada, por otro, a la justificación del drama musical wagneriano como renacimiento en la Modernidad de la comprensión trágica de la música propia de los griegos. Según esta estética, el arte apolíneo (las artes plásticas y, en parte, la poesía) tiene como su carácter más propio la mediación de la imagen y de la palabra con las que se simboliza un ser o figura determinada (es decir, con una identidad que la distingue de todo lo que no es ella). No hay que olvidar que Apolo es el dios griego del principio de individuación, de la mesura y de la claridad. El arte dionisíaco (la música), en cambio, tiene «un carácter y un origen diferentes con respecto a todas las demás artes, pues no es, como éstas, reflejo de la apariencia, sino, de manera inmediata, reflejo (Abbild) de la voluntad misma. Por tanto representa, con respecto a todo lo físico del mundo, lo metafísico, y con respecto a toda apariencia, la cosa en sí»13.

Es decir, en realidad, lo apolíneo y lo dionisíaco no son simples principios estéticos, sino, como Nietzsche los califica expresamente, impulsos o fuerzas artísticas (Kunsttrieb) que brotan de la naturaleza misma y despliegan, con su dinámica, el conflicto o dolor originario que afecta al ser: «Cuanto más advierto en la naturaleza aquellos instintos artísticos omnipotentes y, en ellos, un ferviente anhelo de apariencia, de lograr una redención mediante la apariencia, tanto más empujado me siento a la conjetura metafísica de que lo verdadera-

12 NF 1878, 30[56].

13 NT p. 132. 
mente existente, lo Uno primordial, necesita a la vez, en cuanto es lo efectivamente sufriente y contradictorio, para su permanente redención, la visión extasiante, la apariencia placentera. Nosotros, que estamos completamente cogidos en esa apariencia y que consistimos en ella, nos vemos obligados a sentirla como lo verdaderamente no existente, es decir, como un continuo devenir en el tiempo, el espacio y la causalidad, o sea, como realidad empírica»14. Aquí tenemos la vinculación que el joven Nietzsche establece entre su visión dual del arte griego y la metafísica schopenhaueriana del mundo como voluntad y representación, con todo lo que ésta conlleva de minusvaloración nihilista de la apariencia y de platonismo moral: nuestro mundo fenoménico espacio-temporal, en el que cada cosa está individualizada, no es más que la representación (Vorstellung) o la apariencia (Schein) producida por lo Uno primordial, que es dolor, 'lo eternamente sufriente', ya que necesariamente está obligado a exteriorizarse en este mundo fenoménico en el que alcanza su liberación. El arte apolíneo, como arte de la representación, no es más que símbolo de símbolo, y representa la voluntad de manera mediata, mientras la música, como arte dionisíaco, es la representación 'inmediata' de ese dolor o conflicto de la voluntad como esencia última del mundo.

Es importante percatarse de la actitud que esta metafísica supone, no sólo en relación con el mundo de los fenómenos, sino también con el de la cultura y sus construcciones apolíneas: toda apariencia, toda forma definida procede de este fondo de sufrimiento originario, o sea, de un mal irremediable que afecta al corazón del mundo y a la esencia del ser. Interpretando a esta luz el mito del despedazamiento de Dioniso, Nietzsche dice: «El sufrimiento dionisíaco propiamente dicho equivale a una transformación en aire, agua, tierra y fuego. Nosotros hemos de considerar, por tanto, el estado de individuación como la fuente y razón primordial de todo sufrimiento, como algo rechazable de suyo» ${ }^{15}$. Aquí podemos aproximarnos ya al verdadero significado de aquella romántica 'vuelta a la naturaleza' en favor de la cual también el joven Nietzsche militaba, y obtener una comprensión más exacta de la devaluación correspondiente de la cultura que implica como lugar de la mentira y como pura máscara. Todo lo apolíneo, 
producido por necesidad a partir de la esencia dionisíaca del mundo, termina por disolverse y retornar a su origen. Por tanto, el valor cognoscitivo y liberador no corresponde a las artes apolíneas, que producen sólo máscaras, representaciones de representaciones, sino al arte dionisíaco, a la música, que expresa el movimiento de esa aniquilación en virtud de la cual desaparecen los límites de la individuación y se regresa a la unidad indiferenciada de nuestro ser primordial. La más elevada sabiduría es la que contienen los antiguos misterios griegos, que se deja entrever en la tragedia: «El conocimiento básico de la unidad de todo lo existente, la consideración de la individuación como razón primordial del mal, el arte como alegre esperanza de que pueda romperse el sortilegio de la individuación, como presentimiento de una unidad restablecida» 16 .

De esto es de lo que Nietzsche quiere, en definitiva, desdecirse ahora, de esta comprensión romántica de lo dionisíaco como disolución de la individualidad y advenimiento de la desmesura. Como insinúa en un fragmento antes citado, él presentía vagamente lo que significaba el partido al que estaba afiliado (e incluso se daba cuenta de ello no sin aflicción y espanto), a saber, una lucha contra la cultura en favor de la desmesura bárbara y pre o anti-griega: «Apolo, en cuanto divinidad ética, exige mesura a los suyos y, para poder mantenerla, conocimiento de sí mismo. Y así la exigencia del conócete a tí mismo y del no demasiado va paralela a la necesidad estética de la belleza, mientras que la autopresunción y la desmesura fueron reputadas como demones hostiles, peculiares de la esfera no apolínea, cualidades propias de la época preapolínea, la edad de los Titanes y el mundo de los bárbaros» ${ }^{17}$.

\section{UNA INMENSA FRASE SINFÓNICA}

Cumpliendo el objetivo que El nacimiento de la tragedia se había fijado de cobertura teórico-ideológica del drama musical wagneriano, Nietzsche afirma que la comprensión y el uso de la música como arte dionisíaco, que era propia de los griegos, se perdió en el transcurso de la historia y sólo en el Tristán de Wagner volvía a aquella primera 
autocomprensión y se restablecía aquel uso 'casi religioso' de la música. Porque esta música de Wagner es el verdadero modo de conocer la esencia del mundo, y lo es al consistir en un lenguaje que expresa directa o inmediatamente la relación de lo uno originario con la multiplicidad fenoménica. Es significativo que Nietzsche utilice, para definir este lenguaje, los términos Abbild (reflejo) o Ausdruck (expresión) y no el de Darstellung (representación). Con esto da a entender que la música no es pensada como representación salvo cuando va ligada a elementos apolíneos (la poesía y la imagen), que modulan la inmediatez de su expresividad y la hacen desarrollarse como un arte representativo. Por eso, cuando Nietzsche ejemplifica en el Tristán (y en ninguna otra obra de Wagner ni de ningún otro músico) la nueva encarnación de la música dionisíaca griega, puntualiza que esta ópera debe escucharse "como una inmensa frase sinfónica» ${ }^{18}$, o lo que es lo mismo, prescindiendo del texto y de la puesta en escena.

Es preciso entender, pues, la música dionisíaca como simbolización 'inmediata' del mundo o expresión simbólico-analógica del ser de la naturaleza. Pero, ¿por qué se dice que la música es expresión 'inmediata' de la voluntad cuando, en realidad, es un lenguaje, una expresión mediante sonidos? Lo que se pretende indicar es que se trata de un lenguaje que, a diferencia del lenguaje de las palabras y de los conceptos, es capaz de expresar lo que está más allá de las leyes lógicas, lo que escapa a cualquier determinación y a toda identidad: el querer, la voluntad primordial, la contradicción originaria y el dolor del mundo. La música no es la voluntad, pero se manifiesta como voluntad: «Con el lenguaje (de palabras) es imposible alcanzar de modo exhaustivo el simbolismo universal de la música, precisamente porque ésta se refiere de manera simbólica a la contradicción primordial y al dolor primordial existentes en el corazón de lo Uno primordial y, por tanto, simboliza una esfera que está por encima y antes de toda apariencia» ${ }^{19}$. Lo que hay entre el lenguaje de la música y la voluntad

18 NT p. 170.

19 NT p. 72. «El lenguaje (hablado), en cuanto órgano y símbolo de las apariencias, nunca ni en ningún lugar puede extraverter la interioridad más honda de la música, sino que, tan pronto como se lanza a imitar a ésta, queda siempre únicamente en un contacto externo con ella, mientras que su sentido más profundo no nos lo puede acercar ni un sólo paso, aun con toda la elocuencia lírica» Ibid. 
del mundo es, en definitiva, una analogía estructural en lo referente a la relación entre lo uno y lo múltiple.

Por tanto, si el Tristán de Wagner es un prototipo de lenguaje musical capaz de la más inmediata simbolización dionisíaca y trágica de la voluntad deberá ser porque, sustancialmente, su estructura formal consista en una relación análoga a la que mantienen, en la filosofía de Schopenhauer, el mundo de la representación como mundo de lo múltiple y la voluntad como cosa en sí. Y, en efecto, Wagner crea en esta obra una continuidad y una unidad musicales que disuelven y aniquilan toda identidad y determinación estables. En la concepción clásica y prewagneriana de la música, su desarrollo temporal se organiza a partir de una tonalidad inicial que condiciona unas determinadas posibilidades en función de las leyes de la armonía y el ritmo. El Tristán rompe con estas formas institucionalizadas y prescriptivas de la ópera clásica y, en lugar de la discontinuidad que implica la división del tiempo en recitativos, arias, cantos corales, etc., introduce una continuidad tanto en el nivel armónico como en el melódico: «El acorde del Tristán es un acorde tonalmente indeterminado, que vacila entre el mi menor y el la menor, participa de los dos sin que se pueda decantar hacia una u otra tonalidad. No está pensado armónicamente, o sea, en función de leyes del cuadro tonal y de las modulaciones que autoriza, sino en función de un despliegue temporal imprevisible de la línea melódica que integra notas de modulaciones inesperadas desestabilizando la tonalidad» 20 . Además, mientras el cromatismo era en la música clásica tradicional sólo un elemento accidental en un contexto diatónico, en el Tristán se convierte en algo esencial que contribuye aún más a desestabilizar la tonalidad. Pues la melodía, al integrar sistemáticamente largas apoyaturas en semitono, se constituye a base de disonancias.

20 E. Dufour, «L'année 1872 de Nietzsche: La naissance de la tragédie et Manfred Meditation», Les Cahiers de l'Herne, 2000, p. 248. Para este análisis musical del Tristán, véase S. Gut, «Encore et toujours: L'accord de Tristan», L'Avant-scéne opéra, 34-35 (1981), pp. 148 ss; J. Chailly, Analyse musicale de Tristan et Isolde de Wagner, Paris, Leduc, 1972; T. W. Adorno, Versuch über Wagner, Frankfurt a. M., Suhrkamp, 1962, especialmente cap. III. Y para la comprensión nietzscheana del Tristán cf. G. Liébert, Nietzsche et la musique, Paris, PUF, 1995; G. Campioni, Sulla strada di Nietzsche, Pisa, ETS, 1993, pp. 118 ss y 199 ss; S. Barbera - G. Campioni, Il genio tiranno, Milano, Franco Angeli, 1983. 
En el Tristán, pues, se desarrolla una técnica musical en virtud de la cual se conjuga una continuidad y unidad temporal con la disolución continua de cualquier elemento individualizado e identificable. El procedimiento consiste sustancialmente en desarrollar la melodía sin someterse a exigencias armónicas fijadas de antemano. Se opta, pues, por la independencia de los motivos melódicos y por su imprevisibilidad respecto a las exigencias de la armonía, aunque esto no significa que se prescinde de ésta última. Más bien Wagner crea continuamente tonalidades en un movimiento indefinido que parece no tener final. De hecho, el acorde inicial de Tristán sólo encuentra su resolución en el acorde perfecto en si menor con el que concluye la muerte de Isolda y la ópera misma. La inestabilidad tonal, que aparece ya en el primer acorde, no cesa, de modo que nos es imposible saber en qué tonalidad nos encontramos. Esta indeterminación tonal «está provocada por notas de modulaciones y apoyaturas que contravienen la tonalidad, pero también por el devenir incesante que hace que esta tonalidad se transforme, o sea, por la dimensión temporal y melódica en la que esta música está comprendida... No se pueden fijar aquí momentos precisos a propósito de los cuales podamos decir que se produce una modulación (o sea, que dejamos de estar en una tonalidad para entrar en otra). Las modulaciones sistemáticas, las notas de paso y las apoyaturas tienen por consecuencia el hecho de que el material musical está en continuo devenir. Wagner rechaza toda estabilidad y toda fijeza y nos precipita en la indeterminación y en la incertidumbre ${ }^{21}$. En definitiva, mediante un tratamiento de la melodía como «abreviación de la armonía»22, Wagner crea un flujo ininterrumpido y unitario («una inmensa frase sinfónica») donde no es posible identificar, separar o precisar elementos estables y claramente determinados. Así, la armonía abreviada en la melodía expresa la multiplicidad, mientras la reabsorción de esta multiplicidad en la unidad se produce en virtud de un desarrollo melódico cuya función es restablecer otra vez esa unidad.

Wagner afirma expresamente que, en la música, la armonía es la expresión esencial de la voluntad 'fuera del tiempo y del espacio' (tal como la piensa Schopenhauer), mientras que la melodía es la forma

21 E. Dufour, loc. cit., pp. 248-249

22 NF 1869-1870, 3[54], en KSA 7. 
real de la esencia de la música donde la voluntad se manifiesta en el tiempo ${ }^{23}$. Este es el paralelismo o la analogía que Nietzsche destaca: de igual modo que cualquier nota musical contiene en ella la totalidad de las notas armónicas que va a engendrar, así la voluntad del mundo no puede ser sin un despliegue análogo en la multiplicidad a la que da lugar, o sea, sin esa contradicción que constituye su esencia como dolor: «En la armonía, la voluntad se encuentra en la pluralidad, ella misma fundada en una unidad... El carácter de cada sonido es un poco divergente en sus armónicos superiores. Así, el carácter de cada ser individual es un poco divergente en relación al ser total» 24 . Cualquier nota musical produce una variedad de sonidos en los que se despliega pero sin poderlos unificar. Por ejemplo, el sonido armónico que surge como séptima de la nota sol es el de la nota la subtónica, o sea, fa, que es disonante porque difiere de la serie y es demasiado baja. De modo análogo la voluntad produce el mundo de los fenómenos y pierde su unidad en los seres individuales que crea, lo que hace que cada individuo aparezca como una disonancia en relación a la voluntad primordial.

Así es como la armonía expresa la esencia del mundo - como afirma Schopenhauer-, pues refleja la 'contradicción' en virtud de la cual la unidad engendra una pluralidad de seres individuales. Ahora bien, la voluntad sólo es, de hecho, en el flujo melódico temporal que destruye las figuras claras y distintas de cada ordenación rítmica o de cada paisaje armónico. Esta es la idea que Nietzsche recoge en El nacimiento de la tragedia: la voluntad (la unidad) no forma un trasmundo más allá de los fenómenos, sino que está en la continuidad, en el encadenamiento de los fenómenos que constituye un proceso de nacimiento y descomposición como flujo unitario. Lo que la música del Tristán expresa no es, pues, algo indistinto e indiferenciado, sino que en cada

23 «Mientras la armonía de los sonidos, que no pertenece ni al espacio ni al tiempo, es el elemento propio y verdadero de la música, el músico creador tiende la mano, por así decir, a un entendimiento del mundo de los fenómenos a través de la sucesión rítmica de sus comunicaciones... Mendiante la disposición rítmica de los sonidos el músico entra en contacto con el mundo plástico y concreto por la semejanza de las normas, según las cuales el movimiento de cuerpos visibles se ofrece y es comprensible a nuestra intuición» R. Wagner, «Beethoven» (1870), en Ricordi, battaglie, visioni, ed. E. Pocar, Milano, Ricciardi, 1955, p. 240 .

24 NF 1869-1870, 3[14]. 
momento de su despliegue refleja una determinación que se transforma imparablemente en su contraria. Esta música es el lenguaje verdadero de la esencia de la voluntad porque sólo ella puede simbolizar esta unidad como flujo en el que ninguna identidad es fija ni concluida, sino momento de un devenir temporal de disolución que lo comprende todo. Es el lenguaje capaz de reflejar la unidad del querer justamente mediante la disolución imparable de las identidades musicales individualizadas (armónicas, melódicas y rítmicas) en un devenir continuo. Nos enseña, por tanto, que cada ser es a la vez siempre él mismo y su opuesto, sin que pueda ser abstraído de este devenir que constituye el trasfondo último de su ser (cualquier cosa con una identidad se disuelve en el devenir donde se transforma sistemáticamente perdiendo, por tanto, su identidad y pasando a ser un ser nuevo que desaparecerá a su vez en un movimiento sin fin). Nos simboliza, en definitiva, el modo en que la unidad engendra la multiplicidad, la cual tiene como carácter y destino disolverse y retornar a su origen (todo lo que existe es mera apariencia cuyos límites, apenas esbozados, desaparecen en nuevas figuras que surgen y se desvanecen).

Si aquella sabiduría de la tragedia griega acerca de la unidad de todo lo existente, que entiende — según el Nietzsche de El nacimiento de la tragedia - la individuación como razón primordial del mal, es el conocimiento que se deriva del espíritu de la música comprendida como arte de Dioniso, ahora la filosofía dionisíaca que se propugna, en la que al arte corresponde básicamente la misión de romper el principio de la individuación, debe nacer también de este espíritu de la música que el Tristán de Wagner recupera y hace renacer.

\section{Después del Tristán}

Pero Nietzsche se da cuenta pronto de que uno de los revulsivos más fuertes de su malestar en esta etapa wagneriana de su obra y de su vida lo constituye esta caleidoscópica comprensión romántico-idealista de la música en la que se mezclan elementos, no sólo schopenhauerianos y wagnerianos, sino también hegelianos. Porque la forma en que Wagner piensa la relación de representación en el drama es, esencialmente, dialéctica, de modo que, si se la analiza a fondo, parece más coherente con el proceso sintético hegeliano que con la filosofía de Schopenhauer, hasta el punto de que en Wagner la 
música puede ser vista como representación de una Geistesgeschichte en sentido propiamente hegeliano. Ya en los escritos wagnerianos en torno a 1850 - La obra de arte del futuro, Opera y drama, etc.- Wagner cree que el poeta puro o el músico puro son una consecuencia más de la división del trabajo y del principio de disolución de la cultura que fragmenta y atomiza la sociedad moderna. Él quiere, por ello, crear una obra de arte que exprese la plenitud indivisa, orgánica y original de la que habían gozado los griegos antiguos como hombres totales que vivían en una cultura no fragmentada. Es necesario - pensaba el primer Wagner-, un nuevo lenguaje en el que la poesía no exista más que por la música y ésta, con su poder de evocación y su riqueza simbólica, se despliegue como fuerza de intensificación y concentración del sentimiento y del sentido.

Lo llamativo es que, en Opera y drama y en La obra de arte del futuro, Wagner presenta su propia concepción del drama musical como conclusión de un devenir histórico entendido dentro de los parámetros más puramente hegelianos. En este devenir, la música sólo instrumental de las sinfonías de Beethoven representaría la antítesis de un proceso dialéctico que sólo alcanza su conclusión y cumple su destino cuando, en la Novena sinfonía, con el Himno a la alegría, tiene lugar «la redención del sonido por la palabra»: «La última sinfonía de Beethoven es la redención, desde su elemento más propio, de la música en el arte universal. Esa sinfonía es el evangelio humano del arte del futuro. Tras ella no hay progreso posible, pues a continuación sólo puede venir, inmediatamente, la obra de arte consumada del futuro, el drama musical, para el que Beethoven nos ha forjado la llave artística» 25 . Al desarrollar de manera incomparable las posibilidades de la música instrumental, Beethoven creía elaborar, según Wagner, un lenguaje puramente musical, hasta que siente la irresistible necesidad, como músico, de echarse en los brazos de Schiller, el poeta. Así es como Beethoven, al escribir su última sinfonía, abre el camino a la obra suprema de arte, el drama musical de Wagner ${ }^{26}$.

25 R. Wagner, La obra de arte del futuro, tr. J. B. Llinares y F. López, Valencia, Univ. de Valencia, 2000, p. 139

26 «La más alta obra de arte común es el drama. Éste sólo puede existir en su posible plenitud si se dan cita en él cada una de las modalidades artísticas en su máxima plenitud. El verdadero drama sólo es concebible brotando del afán común de todas las artes por comunicarse del modo más inmediato a la opinión pública común. Cada modalidad artística 
Después de leer a Schopenhauer, Wagner utiliza el nuevo lenguaje de la metafísica schopenhaueriana para dar forma a sus ideas, pero no abandona estas coordenadas dialécticas a la hora de referirse a la relación entre el nivel metafísico de la música, en el que ésta reina de manera incondicional y absoluta, y el nivel de la obra de arte empírica - el drama musical — donde la música no puede surgir sin intervención de otras instancias. He aquí un ejemplo de esta nueva forma de expresarse: «La música, que lejos de representar las Ideas que ocultan las apariencias del mundo, es ella misma una Idea del mundo (y una Idea que lo abarca todo), encierra el drama mientras que el drama mismo expresa la única Idea del mundo adecuada a la música... Así como el drama no dibuja los caracteres humanos sino que hace que ellos se muestren ellos mismos, de forma inmediata, así la música y sus diversos motivos nos llevan a descubrir, según su en-sí, el carácter íntimo de todas las apariencias del mundo. El movimiento, la formación y transformación de los motivos musicales no ofrecen sólo una analogía con el drama. Sólo estos motivos y su evolución pueden hacer clara e inteligible la Idea que expresa el drama» 27 .

Hay un pasaje del Nietzsche maduro que explica así el cambio que se produce en Wagner tras asumir la concepción schopenhaueriana de la música: «De golpe comprendió que se podía hacer más in majorem musicae gloriam con la teoría y la innovación de Schopenhauer, es decir, con la soberanía de la música tal como éste la entendía: la música situada aparte frente a todas las demás artes, la música como el arte independiente en sí, no ofreciendo, como aquellas, reproducciones de la fenomenalidad, antes bien hablando el lenguaje de la voluntad misma, brotando directamente del abismo como su revelación más

individual es capaz, para que se la entienda plenamente, de revelarse a esa opinión mediante la comunicación común con las restantes modalidades artísticas en el drama, pues el propósito de cada una de ellas por separado sólo se logra por completo con la colaboración mutua de todas, haciéndose entender cada una por las otras y comprendiendo por su parte a las demás» R. Wagner, La obra de arte del futuro, p. 143.

27 R. Wagner, Beethoven, p. 271. En La obra de arte del futuro, Wagner había dicho: «Una modalidad artística continúa siendo completamente ella misma si se entrega completamente a sí misma. Pero necesariamente se convierte en su polo opuesto si, al final, tiene que mantenerse enteramente gracias a otra... Pero si se entrega totalmente a otra modalidad, entonces se mantiene totalmente también en ella y es totalmente capaz de pasar desde esa a una tercera para, de ese modo, volver a ser totalmente ella misma, con suma plenitud, en la común obra de arte» R. Wagner, La obra de arte del futuro, p. 108. 
propia, más originaria e inderivada. Con este extraordinario aumento de valor de la música, que parecía brotar de la filosofía de Schopenhauer, también el músico aumentó inauditamente de precio de un modo repentino. A partir de ahora se convirtió en un oráculo, en un sacerdote, e incluso más que un sacerdote, en una especie de portavoz del en-sí de las cosas, en un teléfono del más allá. En adelante ya no recitaba sólo música este ventrílocuo de Dios. Recitaba metafísica. ¿Qué puede extrañar el que un día terminase por recitar ideales ascéticos?» ${ }^{28}$. O sea, Schopenhauer le sirve a Wagner — aunque esto parezca a primera vista imposible y paradójico- para dar otro paso más en su interpretación dialéctica de la música, ya que, a partir de la analogía entre el lenguaje de la música y la voluntad del mundo, Wagner entiende su obra como posibilidad de una síntesis perfecta entre sentimiento y sonido, o lo que es lo mismo, entre lenguaje y realidad.

Uno de los elementos principales de la ruptura de Nietzsche con Wagner lo constituye, sin duda, este giro que, después del Tristán, se plasma en la autocomprensión wagneriana de la ópera y el lugar al que en ella queda reducida la música. En realidad, lo que Schopenhauer dice es lo siguiente: «Todas las posibles aspiraciones, excitaciones y manifestaciones de la voluntad, todos aquellos procesos que se dan en el interior del ser humano y que la razón subsume bajo el amplio concepto negativo de sentimiento, pueden ser expresadas mediante las infinitas melodías posibles, en la universalidad de la mera forma, sin la materia, siempre sólo según lo en-sí, no según la apariencia, como el alma más íntima de esta, sin cuerpo» ${ }^{29}$. O sea, la música puede engendrar imágenes que no serían más que esquemas o ejemplos de su verdadero contenido universal. La música es, por tanto, el lenguaje originario, y este criterio le permite a Nietzsche distinguir entre quienes utilizan las imágenes de los sucesos escénicos, las palabras y afectos de los personajes que actúan para aproximarse, con esta ayuda, al sentimiento musical —o sea, los que «no hablan la música como lenguaje materno»30-, y quienes tienen en la música su seno materno y «se relacionan con las cosas únicamente a través de relacio-

28 F. Nietzsche, La genealogía de la moral, ed. A. Sánchez Pascual, Madrid, Alianza, 1978, p. 120.

29 Citado por Nietzsche, NT p. 134.

30 NT p. 168. 
nes musicales inconscientes»31. En Schopenhauer la música no es tanto el simbolismo de una búsqueda infinita más allá de lo fenoménico, cuanto negación de la realidad como voluntad de vivir y, por tanto, simple forma artística que no aporta, que no capitaliza ningún significado. Más que el trasunto para una posible satisfacción de la Sebnsucht romántica, la música es el modo máximo de negación de la realidadvoluntad como acto de renuncia, como acto de Entsagung.

Esto aclara bastante la posición de Wagner, porque, de hecho, el objetivo de éste no es, en realidad, propiamente la música, sino el drama, dentro del cual la música termina por ser sólo un elemento dialéctico de la representación. En el pensamiento de Schopenhauer, si la música expresa la esencia íntima del fenómeno, o sea, la voluntad, entonces no podría guardar ninguna relación esencial, necesaria, con un libreto de ópera, so pena de convertirse en un simple medio de expresión, en una esclava alienada del fenómeno, perdiendo entonces su propiedad exclusiva, su generalidad unida a una rigurosa precisión. El propio Schopenhauer lo dice así: «Cuando para cualquier escena, acción, suceso, ambiente suena una música adecuada, ésta parece abrirnos el sentido más secreto de aquellos y se presenta como su comentario más justo y claro... Es explicable así que la música haga destacar en seguida con una significatividad más alta toda pintura, más aún, toda escena de la vida real y del mundo... En esto se basa el que a la música se la pueda poner debajo una poesía como canto, o una representación intuitiva como pantomima, o ambas cosas como ópera. Tales imágenes individuales de la vida humana, puestas debajo del lenguaje universal de la música, no se unen o corresponden nunca a ella con una necesidad completa, sino que mantienen con ella sólo una relación de ejemplo fortuito para un concepto universal; representan en la determinación de la realidad lo que la música expresa en la universalidad de la mera forma» 32 . La pirueta dialéctica

31 NT p. 168. «Cuando un músico compone un canto lírico lo que le excita como músico no son las imágenes ni el lenguaje sentimiental de un texto poético, sino que, por el contrario, una excitación musical procedente de otra esfera elige tal texto poético como una expresión analógica de ella misma» NF 1871, 12[1], en KSA 7.

32 Citado por Nietzsche, NT pp. 134-135 (subrayado mío). Por eso Nietzsche considera imposible «hacer música para un poema o querer ilustrar musicalemente un poema con la intención expresa de simbolizar con la música las representaciones conceptuales del poema y procurar así a la música un lenguaje conceptual... Esto sería como si un hijo quisiera engendrar a su padre» NF 1870-1871, 7[127]. 
que Wagner intenta, en cambio, no oculta lo que el maduro Nietzsche señalará ya con determinación, «En Wagner hay, en el punto de partida, alucinaciones, no de sonidos sino de gestos. Por los gestos busca primeramente la semiótica de los sonidos. Si le queréis admirar, ved cómo trabaja: mirad cómo forma pequeñas unidades, y luego las anima, las pone de relieve, las hace visibles. En esto se consume su fuerza, el resto no vale nada»33. Es decir, Wagner es sólo un hombre de teatro, que pone la música al servicio de su virtuosismo teatral, que somete la música a las exigencias del drama el cual queda convertido así, de hecho, en una mera simbólica convencional que sólo sirve para calmar o estimular los nervios de los espectadores. Wagner, en cambio, al poner la música en relación dialéctica con el mundo de la representación dramática, pretende hacer del drama la instancia que define justamente el proceso finito, temporalmente definible, a través del cual se produce efectivamente la posible síntesis entre música y sentimiento, entre lenguaje y mundo, entre lenguaje y realidad. El drama constituye, para Wagner, en definitiva, el lugar ejemplar donde la posibilidad de la conciliación hegeliana se hace efectiva. Y esta es una conclusión que no podría alejarse más del pensamiento de Schopenhauer.

Para Schopenhauer, el que la voluntad del mundo sea incognoscible como cosa en sí implica que las representaciones se comprendan como anonadantes, como aniquilantes. De ahí que sea posible vincular la Entsagung, o sea, la renuncia ascética, con la forma de representación más anonadante que existe del mundo como representación que es la música. Para Wagner, en cambio, como su problema no es el del reconocimiento de la insustancialidad y del vacío de toda apariencia y su redención en el nirvana sino el de la creación del drama, para él la música tiene el valor de una forma representativo-expresiva capaz de realizarse en perfecta coherencia con un significado. Necesariamente, pues, Wagner tiene que dar por supuesto en la búsqueda de la síntesis que el significado se convierte en Idea, y que la representación de esa Idea reviste el carácter de un deber-ser. En Wagner, en definitiva, el valor del drama es el de la representación, y su lenguaje es un lenguaje que vale para describir el espíritu. Por eso, cuando Nietzsche hace un balance de sus obras y de su trayectoria en su obra final Ecce Homo, aproxima abiertamente Wagner a Hegel, el enemigo 
mortal de Schopenhauer, y se refiere a El nacimiento de la tragedia diciendo: «Desprende un repugnante olor hegeliano. Sólo en algunas fórmulas está impregnada del amargo perfume cadavérico de Schopenhauer» 34 .

\section{La vuelta a Apolo}

Wagner no se cansaba de repetir que su música no significaba solamente música, sino algo más que música, incluso mucho más que música35. De ahí que el esfuerzo de su arte, la creación del drama musical, tuviera que estar dirigido a poner en primer plano ese superávit de significado. O sea, la obra de arte es, para Wagner, símbolo, y esto significa en su caso que su forma, su apariencia alude a misterios y a significados ocultos. Es decir, significa que su valor está más allá de su forma. ¿Dónde está? Pues en esa síntesis posible entre sonido y sentimiento, entre lenguaje y mundo que se hace efectiva en el proceso de la representación dramática: «Recordemos que Wagner era un joven en la época en que Schelling y Hegel extraviaban los espíritus. Que él adivinó, tocó con las manos la única cosa que el alemán toma en serio: la Idea, esto es, una cosa oscura, incierta, llena de misterio, pues la claridad entre los alemanes es una objeción y la lógica una refutación... Hegel es un gusto, un gusto que Wagner comprendió, para el cual se sintió hecho, un gusto que él eternizó. Llevó a cabo simplemente su aplicación a la música, encontró un estilo que significa el infinito, fué el heredero de Hegel: la música como Idea»36.

Nietzsche intuye pronto que el templo de lo sublime en el que vive Wagner se asienta, en realidad, sobre el fracaso de la dialéctica hegeliana y de la relación de representación. Porque en el drama wagneriano, la síntesis de música e Idea no se logra, no puede lograrse porque semejante síntesis se escapa continuamente de la estructura y de la forma de la obra. No existe ningún lenguaje que pueda contener en sí dos momentos opuestos, apariencia y realidad, tesis y antítesis, hablar de ambos a la vez y llegar a conciliarlos dialécticamente. Ni la música, ni el drama, ni la lírica, ni la novela son capaces de hacer esa

\footnotetext{
34 F. Nietzsche, Ecce homo, ed. A. Sánchez Pascual, Madrid, Alianza, 1978, p. 68

35 F. Nietzsche, Der Fall Wagner, p. 30.

36 F. Nietzsche, Der Fall Wagner, p. 36.
} 
conciliación, y esta era ya una de las conclusiones de algunos de los representantes de la Frübromantik ${ }^{37}$. Por eso, inevitablemente, cada puesta en escena del drama wagneriano no tiene más remedio que saldarse, cuando se intuye esto, con una directa y desilusionante experiencia de fracaso. El espectáculo en Bayreuth de El anillo del nibelungo no le pareció a Nietzsche accidentalmente falso (mediocridad de los efectos escénicos, de los decorados, de los intérpretes, etc.), sino esencial y necesariamente falso, falso por su propia concepción artística.

¿En qué radica, en último término — se pregunta el Nietzsche maduro-, la profundidad de la música de Wagner? Y se contesta: en su constante intento de sobrepasar sus límites de sentido como lenguaje. El propio Wagner afirmaba que, para poder expresar lo que no se da en los límites de lo finito, la melodía tenía que hacerse infinita. O sea, esta música wagneriana es la música que no se resigna ni se acepta en lo finito, sino que busca una redención en un más allá de lo finito, en un trasmundo infinito. Y esta es la música más diametralmente opuesta a la danza del Dioniso del Nietzsche posterior, que sólo tiene la tierra bajo los pies. El problema de la música de Wagner no está, como Nietzsche terminará viendo, en el abandono de las reglas musicales antiguas, del ritmo, de la armonía, etc., sino que su problema es que no introduce ningún orden en el caos, que no da forma ni crea una apariencia, por lo que carece de una efectividad o efectualidad positiva sobre la vida. La expresividad de esta música no está más que en su abundancia de efectos, es mero efectismo, pura teatralidad: «Óigase sin el drama el acto segundo de El ocaso de los dioses. Es música confusa, delirante como un mal sueño y tan espantosamente indiscreta como si quisiera hacerse oír incluso por los sordos. Este hablar sin decir nada es angustioso» 38 .

Esto es lo que suscita, ya en el período de juventud, las tensiones que obligan a Nietzsche a ir dando entrada a una posición distinta en relación con la cuestión del símbolo, a medida que advierte que el templo de la sublimidad de Wagner se asienta, en realidad, sobre el fracaso de la relación de representación. Sobre el carácter de esta ten-

37 Véase sobre esto mi «Estudio Preliminar» a F. Schlegel, Poesía y filosofía, Madrid, Alianza, 1994.

38 NF 1878, 30[111]. Sobre la 'teatromanía' de Wagner cf. NF 1870-1871, 7[127] y $12[1]$. 
sión arroja luz la oposición que el Nietzsche maduro introducirá (aunque no se debe perder de vista su sentido irónico) entre Wagner y Bizet, como oposición de la ingenua simplicidad de Carmen frente a la sublime profundidad de Parsifal 39 . Esta oposición la planteó Nietzsche no sin connotaciones irónicas, porque oponer a la profundidad wagneriana y alemana de Parsifal el Olimpo de la apariencia no es oponerle la mera superficialidad y frivolidad francesas de Bizet, sino oponerle la obra de arte clásica, o sea, una obra que, en cuanto clásica, se caracteriza por una forma que encaja perfectamente dentro de sus límites. Lo propio del estilo clásico es tener una forma que rehuye todo infinito sin nostalgia por lo inefable. Que es lo mismo que decir que lo que caracteriza a la obra clásica es que es despiadadamente antisimbólica. En este sentido deben entenderse las contraposiciones que Nietzsche propone entre Wagner y Brahms, que es el músico que, para Nietzsche, de modo más honesto se aproxima al pensamiento de Schopenhauer. Al menos esto es lo que parece que cree cuando interpreta obras de Brahms como la Canción del destino (Schiksalslied) o el Requiem alemán. A la primera la ve dividida en dos partes como por un abismo (Abgrund) que no permite ninguna síntesis, sino que la deja reducida a mero formalismo musical. Del Requiem dice que en él se muestra que lo único que atraviesa o envuelve a la vida es la muerte. O sea, en ambos casos Nietzsche destaca que la expresividad de la música de Brahms, y en especial de sus Lieder, radica en la extinción lenta en ellas de la relación semántica y su construcción como mera estructura tautológica o pura perfección formal ${ }^{40}$. Ya no hay ahí ni nostalgia ni melancolía, sino simplemente música. Aun así, Nietzsche pone un reparo a la música de Brahms, y es que esta comprensión de la incapacidad simbólica del lenguaje musical se resuelve, a veces, en él en pesimismo, lo mismo que en Schopenhauer, dando lugar a un juicio negativo de valor. Por eso Nietzsche termina diciendo que incluso la música de Brahms es, para él, todavía demasiado profunda,

39 Cf. F. Nietzsche, Der Fall Wagner, p. 14.

40 En un primer momento, Nietzsche condena la estética musical formalista de Hanslick: «Hanslick no encuentra el contenido y piensa que sólo existe la forma» NF 1871, 9[8], se adhiere luego a ella contra Wagner. Cf. G. Guanti, Romanticismo e musica. L'estetica musicale da Kant a Nietzsche, Torino, EDT, 1981, Introducción y cap. XI; E. Dufour, «L'esthétique musicale formaliste de Humain, trop humain», Nietzsche Studien, 28 (1999). 
porque lo que él busca, como música verdaderamente dionisíaca, es una que tan sólo diga que hay danza y ningún enigma.

\section{LA TRAGEDIA COMO TRANSFORMACIÓN MÁGICA}

Pero esto debe ser cuidadosamente entendido, pues estamos ante uno de los rasgos de la originalidad del planteamiento de Nietzsche ya en su etapa de juventud, que no debería prestarse a malentendidos. Pues este quererse ir definitivamente al Olimpo de la apariencia, a la vista del vacío simbolismo del genio de Wagner, tiene como reverso la comprensión nietzscheana de la tragedia, que de manera trabajosa trata de abrirse paso, y que sólo en alusiones y presentimientos se deja bien entrever. En este contexto me parece esencial que la afirmación nietzscheana de la apariencia sea entendida en conexión con la ascesis consciente de la forma pura que únicamente se reconoce efectividad en lo relativo, no a su capacidad de simbolizar trasmundos, sino en lo que respecta a su efectividad como instrumento o medio de poder hacer formulable y dominable un mundo, o sea, como efectividad para la vida, para potenciar y desarrollar la vida. De ahí que el forcejeo de Nietzsche con Wagner y el contenido de sus observaciones al drama musical anticiparían argumentos en cierto modo parecidos a los expresados luego por Max Weber en relación con la lógica del proceso de racionalización ${ }^{41}$.

El Wagner de los años 1860-70, que ha leído ya a Schopenhauer, no piensa, ciertamente, que en el drama musical el texto tenga la

prioridad y que la música haya de estar a su servicio. Introduce, como hemos visto, una cierta relación dialéctica entre música y representación cuyo núcleo más significativo queda explícito en pasajes como éste: «La poesía (la palabra) no tiene el poder de determinar la música, sino que sólo el drama (la acción dramática) puede tener ese efecto» ${ }^{42}$. Es decir, no es el libreto como palabra poética sino la acción - que se desarrolla ante nosotros como acompañamiento visible de la música - la que tiene la prioridad. Aquí está el núcleo del desacuerdo y el mejor lugar para entenderlo. Para Nietzsche, el drama no

41 Cf. M. Weber, «Fundamentos racionales y sociológicos de la música», en Economía y Sociedad, tr. E. Imaz y otros, México, FCE, 1979, pp. 1118-1183.

42 R. Wagner, Beethoven, p. 251. 
significa esencialmente la acción. En su origen, en la tragedia griega primitiva el coro era más importante que la acción: «Ha sido una auténtica desgracia para la estética que se haya traducido siempre la palabra drama por acción... El drama antiguo tenía lugar en vistas a grandes escenas declamatorias, lo que excluía la acción» ${ }^{33}$. En realidad esta era la tesis vertebral del primer libro de Nietzsche. De igual modo que el efecto catártico de la tragedia ática procede de la vida eterna del núcleo de la existencia en medio de la constante desaparición de las apariencias 44 , así el simbolismo del coro de los sátiros expresaría ya en un símbolo la relación primordial que existe entre la cosa en sí y la apariencia ${ }^{45}$. El coro de sátiros es, por tanto, ante todo, una visión tenida por la masa dionisíaca, de igual modo que el mundo del escenario es, a su vez, una visión tenida por ese coro de sátiros ${ }^{46}$. En conclusión, la transformación mágica, y no la acción, es el presupuesto de todo arte dramático: «La excitación dionisíaca es capaz de comunicar a una masa entera ese don artístico de verse rodeada por semejante muchedumbre de espíritus, con la que ella se sabe íntimamente unida. Este proceso del coro trágico es el fenómeno dramático primordial: verse uno transformado a sí mismo delante de sí, y actuar uno como si realmente hubiese penetrado en otro cuerpo, en otro carácter... Aquí hay ya una suspensión del individuo, debida al ingreso en una naturaleza ajena» ${ }^{47}$.

En todo caso, hay que tener en cuenta, a este respecto, la razón de la diferencia que, para Nietzsche, hay entre los griegos dionisíacos y los bárbaros dionisíacos. El dionisismo de los griegos está impregnado y modelado por lo apolíneo, por las formas apolíneas que logran sublimar y espiritualizar las energías vitales de lo dionisíaco. Para Nietzsche, la representación trágica no sería soportable si el mito, la imagen y la palabra (elementos apolíneos) no nos protegiesen de la violencia de lo dionisíaco en su inmediatez. Sin la intervención del

43 F. Nietzsche, Der Fall Wagner, § 9, nota, p. 9.

44 «Sólo partiendo del espíritu de la música comprendemos la alegría por la aniquilación del individuo. Pues es en los ejemplos individuales de tal aniquilación donde se nos hace comprensible el fenómeno del arte dionisíaco... El héroe, apariencia suprema de la voluntad, es negado para placer nuestro, porque es sólo apariencia, y la vida eterna de la voluntad no es afectada por su aniquilación» NT p. 137.

45 NT p. 81.

46 NT p. 82.

47 NT pp. 83-84. 
dios de la bella apariencia, que en la Grecia antigua transforma en fenómeno estético lo espantoso del dionisismo (hecho de voluptuosidad y de crueldad), seríamos aniquilados por la música: «La tragedia absorbe en sí el orgiasmo musical más alto, de modo que es ella la que, tanto entre los griegos como entre nosotros, lleva directamente la música a su perfección. Pero luego sitúa junto a ella el mito trágico y el héroe trágico, el cual entonces, semejante a un Titán poderoso, toma sobre sus espaldas el mundo dionisíaco entero y nos descarga a nosotros de él»48. Esta es la relación exacta entre música y representación. La música no existe si no es ya como forma fenoménica ella misma, como mero lenguaje, como ordenación rítmica sin la cual no podría ser perceptibe. Por tanto, también la música es una forma apolínea ${ }^{49}$. No hay música pura e inmediatamente dionisíaca, sino sólo música como forma, como lenguaje.

Así, si en los primeros pasos de la tragedia, música, palabra e imagen surgen simultáneamente, al no tener lugar esto ya hoy la música debe ser lo primero, lo único, lo incondicionado. Esta era la idea, un tanto imprecisa todavía, que presidía el análisis y la valoración que Nietzsche hizo del Tristán de Wagner. El Tristán puede ser considerada una reencarnación de la tragedia ática en la medida en que en esta ópera el papel del coro lo representa la orquesta, lugar de la visión dionisíaca, de la cual la escena, como un reflejo, es su emanación. La tesis filológica de Nietzsche que, como hemos visto, era que en su origen la tragedia se reducía al coro, caracterizado por una armonía simple y la riqueza de sus medios de expresión rítmica, parece poder encajar en Tristán de alguna manera. Pues, si en la tragedia griega, «la estructura de los períodos musicales y rítmicos que seguía el texto en un paralelismo estrecho estaba acompañada por el movimiento de la danza, de modo que las evoluciones de los coreutas que se dibujaban ante los ojos de los espectadores como arabescos sobre la ancha superficie del escenario daban a experimentar como una música hecha de alguna manera visible» ${ }^{50}$, en el Tristán — respecialmente en su segundo y tercer actos- Nietzsche subraya cómo las voces se asimilan a instrumentos hasta el punto de fundirse con la orquesta. Ve, pues, en

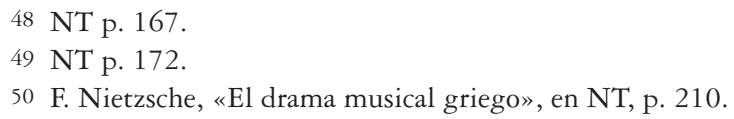


él un cierto restablecimiento del coro que, asociado a la orquesta, tiene una visión y describe en el entusiasmo lo que ve. Por encima de él está el mundo de la imagen, el mimo, en la pureza reencontrada de la escena.

\section{MÚSICA, SÓLO MÚSICA}

La concepción que el joven Nietzsche tiene del drama no es, pues —ni siquiera en esta etapa de juventud-, la de Wagner. Nietzsche sustituye la acción — situada ya por Aristóteles como núcleo del drama- por una Stimmung creada por la música. En el escenario, liberada de las antiguas condiciones prescriptivas, la música debe brillar realmente sola, generando vitalidad: «Algunos caminos le quedan abiertos todavía a la música: composición orgánica como sinfonía con un equivalente como drama (¿O mimo sin palabras?), y luego la música absoluta, que recupere las leyes de la composición orgánica y no utilice a Wagner nada más que como preparación ${ }^{51}$. Es correcto, pues, situar a Nietzsche en la tradición de la música absoluta, pero a condición de que también aquí se lleven a cabo algunas matizaciones. El grado de afinidad del pensamiento de Nietzsche con el concepto de la música absoluta tiene una relación inversamente proporcional a su acuerdo y proximidad con las ideas de Wagner, hasta el punto de que puede decirse que el concepto originalmente nietzscheano de la tragedia lo que busca - en parte inconscientemente en la etapa de juventud- es mostrarse finalmente como lo opuesto al drama wagneriano.

Si no hay nada que garantice la identidad de música y mundo, entonces una música como la de Wagner, que aspira a presentarse como símbolo metafísico, como alusión y revelación de algo distinto de sí, no es más que, a la vez, una música falsa y mala. Es, como dice el Nietzsche maduro, «el mal estilo en música»52. Es falsa porque, como he dicho antes, quiere expresar más de lo que los límites de su carácter de mero lenguaje le permiten. Y es mala porque su pretendida expresividad mixtifica y pervierte la auténtica seriedad trágica del pesimismo, que acepta valientemente la ausencia de trasmundos en

51 NF 1878, 30[112].

52 F. Nietzsche, Der Fall Wagner, p. 15. 
los que liberarse. El buen estilo en música sería, por tanto, la música absoluta, de la que, paradójicamente, Nietzsche mismo reconoce anuncios y ejemplos en la música de Wagner: «Se le escapan breves pasajes de buena música, casi siempre en contradicción con el drama»53. Ahora bien, la paradoja es aquí sólo aparente. Porque si hay en la música wagneriana anuncios de la música absoluta, se debe a que, al fracasar en su intento de representar la Idea, esta música se queda reducida a puro signo, a pura forma, a pura apariencia linguística: «Accesos de belleza: escenas de las hijas del Rin, luces refractadas, profusión de colores como en el sol de otoño, abigarramiento de la naturaleza: rojo ardiente, púrpura, amarillo y verde melancólicos fluyendo entremezclados» $\$ 4$. Al fracasar en su afán redentor, la entera teatralidad wagneriana se deconstruye a sí misma y entonces suena como mera música, la pura música que supieron descubrir figuras como Gustav Mahler o Arnold Schönberg. Para ellos, Wagner fue genial no por la idea global de sus obras, sino por sus fragmentos breves, por pentagramas de cinco a quince compases perdidos aquí y allá, en preludios, intermedios y oberturas.

O sea, la dilatación infinita del lenguaje musical descubre su esencia decadente, plenamente moderna, que es como decir que descubre su vacío y la debilidad de su necesidad de consuelo y de redención. Cada vez que se representa, la música de Wagner es una confesión abierta de esta debilidad, aparece como imagen de esta necesidad de redención, y esto deconstruye su propia pretensión abatiendo lo sublime. Se deconstruye su valor utópico, o sea, en términos weberianos, se desencanta, de modo que la aparente plenitud de su forma se muestra como nada.

Conclusión: lo que se muestra tras el fracaso de Wagner es que no existe ninguna esencia oculta en el significar de la música, ni relación originaria entre signo y significado, ni lenguaje como representación perfecta de un sentimiento o de un mundo. Todo indicio de expresar más que sí misma, toda posible connotación metalinguística, todo afán de querer decir sus propios fundamentos metafísicos, subjetivos o utópicos, tiene que ser rechazado. Esta es, a la vez, la miseria y la grandeza trágicas de la música absoluta. Que su escritura ya no es 
escritura de ninguna nueva totalidad ni de ninguna nueva síntesis, sino aceptación de una separación, de una desvinculación completa respecto de cualquier originario, o sea, pura apariencia.

$Y$ este es también el sentido original que para Nietzsche tiene la tragedia. Como en Schopenhauer, también el concepto de tragedia en Nietzsche implica una determinada forma de negación, o sea una forma de ascetismo, un radical acto de Entsagung. Lo propio de Nietzsche es que, para él, esa renuncia significa un asumir y afirmar trágicamente que no hay misterios metafísicos inefables, que todo trasmundo es nada, y que el mundo no es más que la apariencia de nuestras formas de lenguaje. Eso es lo que significa el amor fati, el amor del destino que se representa en la tragedia, el amor y la afirmación de nuestro destino como vida circunscrita a la apariencia sin nostalgia de la conciliación ni búsqueda de la liberación. Por tanto, en el concepto nietzscheano de tragedia también Vernichtung como aniquilación efectiva de cualquier utopía simbólica, y no la wagneriana Verdichtung como poetización/concentración de lo simbólico. 